\title{
RADIATION DOSE AND ANATOMICAL INFORMATION IN SACRUM BONE EXAMINATION WITH AP AND AXIAL AP PROJECTIONS
}

\author{
Rini Indrati ${ }^{a^{*}}$; Siti Daryati ${ }^{\mathrm{b}}$; Dewi Kartikasari ${ }^{\mathrm{c}}$; Sri Mulyati ${ }^{\mathrm{d}}$; Marichatul Jannah ${ }^{\mathrm{e}}$ \\ a,b,d,e Poltekkes Kemenkes Semarang ; Tirto Agung street ; Pedalangan Banyumanik \\ Semarang 50268 ; Indonesia \\ ${ }^{c}$ National Atomic Energy Agency Indonesia ; 49 Lebak Bulus Raya street \\ Jakarta 12440; Indonesia
}

\begin{abstract}
The projections for the sacrum are axial anteroposterior with the beam 15 degrees toward the cephalad, and axial posteroanterior in the direction of the beam 15 degrees caudally. Some practitioners take steps to examine the sacrum with AP projections in a perpendicular beam direction. Around the sacrum are reproductive organs that are sensitive to radiation, so it is necessary to select the right projection to reduce the radiation dose and show clear anatomical information. This study aims to determine the projection of an examination that produces clear anatomical information at a minimal dose. This is an experimental study with one shot post-test only. Samples in the form of radiographs were obtained from perpendicular AP and axial AP projections assessed by radiologists regarding the clarity of anatomical information. The radiation dose was measured using TLD on the ovaries and gonads. Data were analyzed by t-test and Wilcoxon test with an error level of 5\%. The AP axial projection shows better anatomical information than the perpendicular AP projection. The axial AP projection shows a smaller dose of the ovaries and gonads. There is a difference in anatomical information between AP and axial AP projections with a $\mathrm{p}$-value $=0.017$. There was a difference in radiation dose between AP and axial AP projections on the right ovary ( $\mathrm{p}$-value $=0.002)$, left ovary $(\mathrm{p}$-value $<0.001)$ and gonads $(\mathrm{p}$-value $=0.008)$.
\end{abstract}

Keywords: sacrum bone; AP; axial AP projection; anatomical information; radiation dose

\section{Introduction}

X-rays are the most widely used source of ionizing radiation for diagnostic testing in clinical applications (Bushong, 2016). Radiodiagnostic examination is one of the utilization of ionizing radiation to confirm the diagnosis results needed by patients to identify abnormalities of a patient, with minimal radiation exposure but provides good quality medical imaging (Abrahams, 2015).

In 2000 the number of routine radiological X-ray examination diagnostics carried out around the world are reported to be around 1910 million, with collective dose effective and per capita doses of 2.3 million $\mathrm{m}-\mathrm{Sv}$ and $0.4 \mathrm{mSv}$

*) Corresponding Author (Rini Indrati)
E-mail: riniindrati@poltekkes-smg.ac.id respectively. The number of examinations increased to 3100 million, with a collective effective dose being 4 million Sv-man and a per capita dose of $0.6 \mathrm{mSv}$. From the two data, it can be seen that in the past eight years there has been an increase in the number of examinations of more than $60 \%$, followed by an increase in the collective effective dose of $74 \%$ per capita dose by $50 \%$ (Ballinger, 2016).

Sacrum bone is one of the objects examined with conventional radiodiagnostic. Sacrum bone examination techniques, there are several positions, namely the Antero-posterior axial with the beam direction 15 degrees to the cephalad, the posteroanterior axial with the beam direction 15 degrees caudal, and lateral with the beam direction perpendicular (Gonzalez 2013)(Ballinger, 2016). On examination of the 
sacrum bones, there are several other critical organs such as the gonad and ovary that are sensitive to ionizing radiation (Gonzalez, 2013)(Ballinger, 2016) (Eric, 2013).

Quality radiographs are influenced by a geometric and non-geometric factor (Bushong, 2016). On radiological examination of the sacrum bones around, there are sensitive organs to radiation, namely the ovary and gonads (Ballinger, 2016). In addition to the quality of radiographic radiation protection must be a major concern in radiodiagnostic examination. (Indrati, 2017) (Akhadi, 2000). Radiation has a negative effect in the form of stochastic and non-stochastic effects (deterministic] (Indrati, 2017) (Akhadi, 2000) (Statkiewcz, 2006).

In the hospital, sacrum examinations are often performed by adjusting the direction of the beam perpendicularly. In the examination of the sacrum around the object, there are reproductive organs that are sensitive to radiation, including the ovaries and gonads, so it is necessary to pay attention to the dose received from each organ according to the dosage reference. The difference in the use of projections and the direction of irradiation will affect the position and distance of the object to the Image Receptor so that it will also affect the clarity of anatomical information and affect the acceptance of radiation-sensitive organs (Bushong, 2016). This study aims to determine a good projection in displaying anatomical information and the dose received by sensitive organs.

\section{Method}

This type of research is experimental using a two-group one-shot post-test only design.

Experimental design as follows:

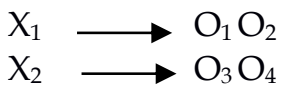

$\mathrm{X}_{1}=\mathrm{AP}$ Projection

$\mathrm{X}_{2}=$ Axial AP Projection

$\mathrm{O}_{1}=$ Anatomic Information on AP Projection

$\mathrm{O}_{2}=$ Radiation doses of Sensitive Organs on AP Projection

$\mathrm{O}_{3}=$ Anatomical Information on Axial AP Projection

$\mathrm{O}_{4}=$ Radiation doses of Sensitive Organs on Axial AP Projection

Phantom arrangement in radiographic image creation and TLD placement in the reproductive organs as shown in Figure 1.

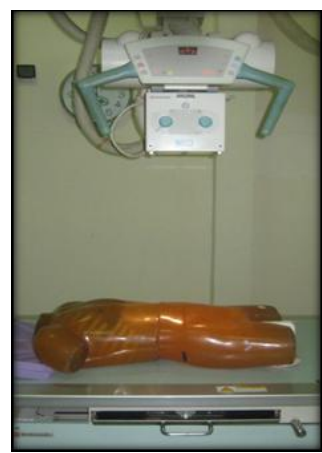

(A)

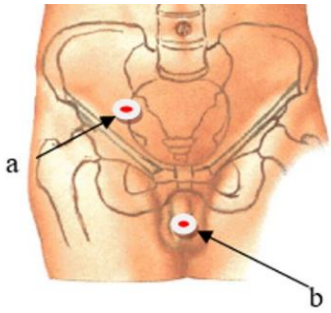

(B)
Figure 1. (A) Phantom position adjustment. (B) Placement of TLDs on the ovaries (a) and gonads (b)

The study was conducted by making a sacrum radiograph on the $\mathrm{AP}$ and $\mathrm{AP}$ axial projection. Radiographs are assessed by two radiology specialists with the equivalent of a minimum of 10 years of experience. Anatomy was assessed using a checklist covering the clarity of the anatomy of the Lumbar 5-Sacral 1 joint, Superior articular process of the sacrum, Sacral foramina, Apex of sacrum and Sacroiliac joints using unclear, self-explanatory and clear criteria. The radiation dose is measured by placing TLDs on the ovaries and gonads. Radiographs and dose measurements were repeated nine times for each projection. The research sample is a radiographic examination of the sacrum bone with nine radiographs of the pelvic phantom using $\mathrm{AP}$ and Axial $\mathrm{AP}$ projections with FFD $100 \mathrm{~cm}, \mathrm{kV}=70$, and $\mathrm{mAs}$ $=20$. Data analysis was performed using paired t-est and Wilcoxon test with 95\% Confidence Interval.

\section{Results and Discussion}

Radiographs generated from the two AP Projections and the Axial AP Projection as shown in figure 2.

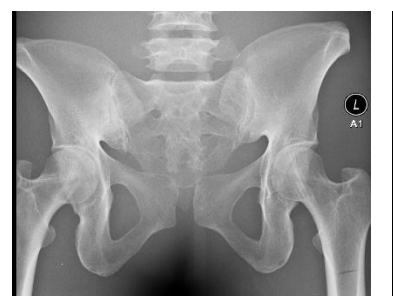

(a)

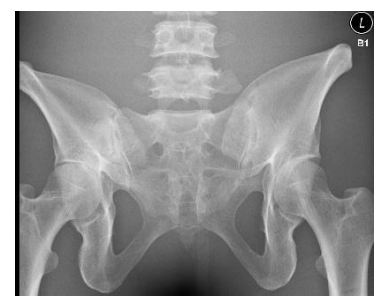

(b)
Figure 2. Radiographs of the sacrum bone (a) AP Projections, (b) Axial AP Projections. 
The results of the radiologist's assessment of the clarity of the sacrum anatomical information in both projections are shown in Table 1 and Table 2. The assessment includes the anatomical clarity of the Lumbar 5-Sacral 1 Joint, Superior articular process of the sacrum, Sacral foramina, Apex of sacrum and Sacroiliac joint with criteria unclear, sufficiently clear and Clear.

Table 1. Results of Assessment of Clarity Information Anatomy Sacrum bone AP Projection

\begin{tabular}{lccc}
\hline \multicolumn{1}{c}{ Anatomy } & $\begin{array}{c}\text { Unclear } \\
(\%)\end{array}$ & $\begin{array}{c}\text { Sufficiently } \\
\text { clear }(\%)\end{array}$ & $\begin{array}{c}\text { Clear } \\
(\%)\end{array}$ \\
\hline $\begin{array}{l}\text { Lumbar 5-Sacral } 1 \\
\text { Joint }\end{array}$ & 0 & 22.2 & 77.8 \\
$\begin{array}{l}\text { Superior articular } \\
\text { process of sacrum }\end{array}$ & 0 & 77.8 & 22.2 \\
Sacral foramina & 0 & 88.8 & 11.1 \\
Apex of sacrum & 0 & 100 & 0 \\
Sacroiliac joint & 0 & 66.7 & 33.3 \\
\hline
\end{tabular}

Clarity of anatomy information on Sacrum Bone AP projections mostly considered Sufficiency clear on the anatomy of the Superior Articular process of Sacrum (77.8\%), Sacral Foramina (88.8\%), and Apex of Sacrum (100 0\%), Sacriliac joint $(66,7 \%)$, whereas AP Projection is considered better for showing Lumbar 5- Sacral 1 Joints $(77.8 \%)$.

Table 2. Results of Clarity Assessment of Sacral Anatomical Information on Axial AP Projection

\begin{tabular}{lccc}
\hline \multicolumn{1}{c}{ Anatomy } & $\begin{array}{c}\text { Unclear } \\
(\%)\end{array}$ & $\begin{array}{c}\text { Sufficiently } \\
\text { clear }(\%)\end{array}$ & $\begin{array}{c}\text { Clear } \\
(\%)\end{array}$ \\
\hline $\begin{array}{l}\text { Lumbar 5-Sacral } 1 \\
\text { Joint }\end{array}$ & 0 & 11.1 & 88.9 \\
$\begin{array}{l}\text { Superior articular } \\
\text { process of sacrum }\end{array}$ & 0 & 33.3 & 66.7 \\
Sacral foramina & 0 & 33.3 & 66.7 \\
$\begin{array}{l}\text { Apex of sacrum } \\
\text { Sacroiliac joint }\end{array}$ & 0 & 44.4 & 55.6 \\
\hline
\end{tabular}

Clarity of Information anatomical sacrum bone in Axial AP projections stated that axial AP clearly shows good anatomical information in the Lumbar 5 - Sacral 1 joint $(88.9 \%)$, Superior Articular Process of Sacrum (66.7\%) Sacral Foramina $(66,7 \%)$ Apex of the sacrum $(55.6 \%)$ while the Sacroiliac Joint is mostly considered sufficiently clear $(66.7 \%)$.

The radiation dose received by sensitive organs around the Sacrum bone consisting of the right ovary left ovary and Gonads as in table 3. The radiation dose received by the organ sensitive to sacrum bone examination showed that on Axial AP Projection organs Sensitive received the smaller than AP Projection.

Table 3. Radiation Doses received by sensitive Organs around the bones of the Sacrum

\begin{tabular}{lcc}
\hline \multirow{2}{*}{ Organs } & \multicolumn{2}{c}{ Dose $(\mathrm{mSv})$} \\
\cline { 2 - 3 } & AP Projection & $\begin{array}{c}\text { Axial AP } \\
\text { Projection }\end{array}$ \\
\cline { 2 - 3 } & Mean \pm SD & Mean \pm SD \\
\hline Right Ovary & $1.653 \pm 0.067$ & $1.611 \pm 0.011$ \\
Left Ovary & $1.659 \pm 0.018$ & $1.587 \pm 0.050$ \\
Gonad & $1.341 \pm 0.014$ & $1.220 \pm 0.007$ \\
\hline
\end{tabular}

Based on the assessment of a radiology specialist to the clarity of anatomical information, a different test was performed using the Wilcoxon test. The results of the different test results for clarity of anatomical information on the two projections of the sacrum examination are shown in Table 4.

Table 4. Results of different tests Anatomical Information of Sacrum Bone information between the AP and Axial AP Projections

\begin{tabular}{lcc}
\hline \multicolumn{1}{c}{ Variable } & Mean Rank & p-value \\
\hline AP Projection & 1.11 & 0.017 \\
Axial AP Projection & 2.06 & \\
\hline
\end{tabular}

Test for different clarity of anatomical information sacrum bone shows a significant difference with $\mathrm{p}$-value $=0.017$. Axial AP Projection can show clearer anatomic information with a mean Rank of 2.06. The results of different tests to see the difference in the clarity of information on each anatomy in the Sacrum Bone examination is shown in table 5 .

Table 5. Results of different test Anatomical Information clarity anatomical sacral bone between AP projections and Axial AP Projections

\begin{tabular}{llc}
\hline \multicolumn{1}{c}{ Variable } & \multicolumn{1}{c}{ Anatomy } & p-value \\
\hline & Lumbar 5 - Sacral 1 Joint & 0.779 \\
AP & Superior Articular Process of & 0.072 \\
Projection & Sacrum & \\
Axial AP & Sacral Foramina & 0.032 \\
Projection & Apex of Sacrum & 0.001 \\
& Sacro iliac joint & 0.015 \\
\hline
\end{tabular}

The AP and Axial AP projections showed no significant difference in the clarity anatomical information of Lumbar 5-Sacral 1 joint ( $p$-value = 0.779 ) and anatomy superior articular process of the sacrum $(p$-value $=0.072)$. Test results for anatomical information clarity showed there were differences in the anatomical information clarity of Sacral Foramina with a value of $p=$ 
0.032, Apex sacrum ( $\mathrm{p}$-value $=0.001)$, and sacroiliac joints $(p$-value $=0.015)$.

A different test is carried out to determine the difference in radiation dose received by sensitive organs (right ovary, left ovary, and gonad). The dose was measured using ESE (Entrance Skin Exposure). Entrance Skin Exposure (ESE) is used as a method of measuring the dose of radiation received by the organ because it is the most likely method used to measure the estimated dose received by the ovaries and gonads. Test results of different radiation doses received by the right ovary as in table 6 .

Table 6. Results of different test radiation dose in the right ovary on AP and Axial AP projections

\begin{tabular}{lcc}
\hline \multicolumn{1}{c}{ Variable } & Mean SD & p-value \\
\hline AP Projection & $1.653 \pm 0.067$ & 0.011 \\
Axial AP Projection & $1.611 \pm 0.011$ & \\
\hline
\end{tabular}

Test results indicate that there is a difference in right ovary radiation dose between AP Projection and Axial AP Projection ( $p$-value = 0.011). AP projections produce higher right ovary doses than the AP Axial Projection. Doses received by the left ovary Sacrum bone examination projections are as in table 7.

Table 7. Results of different radiation dose received in the Left Ovary between the AP and Axial AP Projections

\begin{tabular}{lcc}
\hline \multicolumn{1}{c}{ Variable } & Mean SD & p-value $^{* *}$ \\
\hline AP Projection & $1.659 \pm 0.018$ & 0.013 \\
Axial AP Projection & $1.587 \pm 0.050$ & \\
\hline
\end{tabular}

The test results show the difference in radiation dose received by the left ovary between AP projections and Axial AP Projection with p-value $=0.001$. The results of the different radiation dose tests received by the left ovary showed a significant difference between the AP and AP Axial projections ( $p$-value $=0.013$ ). The different dosage tests received by the gonads pass through three sacral bone projections as in table 8 .

Table 8. Results of different Tests of the radiation dose received in the Gonad between the AP and Axial AP Projections

\begin{tabular}{lcc}
\hline \multicolumn{1}{c}{ Variable } & Mean SD & p-value $^{* *}$ \\
\hline AP Projection & $1.341 \pm 0.014$ & 0.008 \\
Axial AP Projection & $1.220 \pm 0.007$ & \\
\hline
\end{tabular}

The test result showed there were differences in radiation doses received by Gonad on examination of the sacral bone between AP and Axial AP with a p-value of 0.008. Gonad received the lower dose in the Axial AP Projection.

The minimum radiation dose and the best anatomical information is determined based on the anatomical clarity and the smallest radiation dose received by the organ. Radiation doses in the right ovary, left ovarian doses and smaller gonadal doses are accepted on axial AP projections. Likewise, overall information on Sacrum bone anatomy is also shown by axial AP projections. Axial AP Projection is a better projection compared to AP projection to show images of Sacrum bones with a minimum dose.

Results of the study showed that there are differences in anatomical clarity between the AP and Axial AP projections. Axial AP projection can show the overall anatomy of the sacrum bone more clearly than the AP projections. The ability of axial AP projection shows better anatomical information than the other two projections, especially in describing the anatomy of the sacrum foramen, sacrum bone apex, and sacroiliac joint.

The radiograph's ability to show clear anatomical information of an object is determined by the contrast and quality of the radiograph. Radiograph contrast is influenced by the object being photographed including thickness, density, atomic number, and X-ray quality $(\mathrm{kV})$. Apart from the object being examined, the image recorder (Screen film system), scattering and fog play a role in producing a good radiograph (Bushong, 2016). The second factor that determines the clarity of image information is the quality of the radiograph. The quality of the radiograph is determined by several factors, namely radiographic mottle, sharpness, detail (resolution), and distortion (Bushong, 2016) (Papp, 2006).

Geometric factors are one of the factors that determine the quality of a radiograph. Geometric factors include the distance between the light source and the image reorder / focus film distance (FFD), the distance between the object and the film / film object distance (OFD) and the size of the focal spot. In the radiograph examination of the sacrum, the two projections used by the AP and the AP Axial were adjusted to the same FFD, which was $100 \mathrm{~cm}$ and made with the same X-ray equipment so that it could be ascertained that the sizes of both focal spots 
were the same. What distinguishes between the two is the distance between the object and the image recorder (IR), the location of the object against the center beam, the use of angled rays and the position of the object towards the Image Receptor (IR). In the AP projection, the distance of the sacrum to the film is closer than the AP axial projection. OFD affects the size of the resulting object (Bontrager, 2014).

Sacrum AP projections have relatively no enlargement (Distortion in Size) compared to the other two projections. However, when viewed from the position of sacrum bone objects in the $\mathrm{AP}$ position forming an angle to the Image recorder, this results in the resulting shadow will experience a change in shape (distortion in shape) that is experiencing a shortening (Foreshortening) (Bushong, 2016) (Bontrager, 2014). The presence of distortion in this form causes the anatomy of the sacrum to be less visible than the other projections (Axial AP Projection). This closest distance also causes organs sensitive around the sacrum (ovary and gonads) to get a greater dose than the other two projections (Bushong, 2016) (Papp, 2006).

In Axial AP Projection, the Beam is set at 15 degrees Cephalad with a point at 2.5 inches above the symphysis pubis. By adjusting the angle of the beam toward the cephalad, the center of the beam will be perpendicular to the sacrum bone object which anatomically has a curved shape, this will reduce the distortion in shape so that the sacrum bone is seen in a wider size. On the Axial AP projection, the foramen sacrum is more clearly visible than the AP projection. On the AP projection, some of the sacrum bone apexes is still overlapping with the symphysis pubis bone, the sacroiliac joint is less visible open The difference in anatomical clarity is due to the beam direction, the position of the object towards the center of the beam and the position of the object towards the Image recorder) (Bontrager, 2014) (Bushong, 2016).

The results showed there were differences in the value of radiation doses received by sensitive organs around the sacrum organs including the right ovary, left ovary, and gonads. The difference in dose received by the organ is determined by the distance of the organ to the source of radiation in this case the X-ray tube. In this study, all three projections inset with $100 \mathrm{~cm}$ FFD. In AP projection the distance of the ray source to the reproductive organs is closer compared to the Axial AP projections. This results in the dose received by the ovary and gonad organs getting the higher surface dose compared to Axial AP projections.

The deterministic effect on male reproductive organs (gonads) is sterility (Yoder, 2010). Exposure to radiation in the testes will disrupt the process of sperm cell formation which will ultimately affect the number of sperm cells to be produced. The radiation dose of 0.15 Gy $(0.15 \mathrm{~Sv})$ is a temporary sterility threshold dose because it has resulted in a decrease in sperm cell counts for several weeks. While the threshold dose for permanent sterility is $3.5-6$ Gy (3.5-6 Sv) (Akhadi, 2000)(Daryati et al., 2018).

The effect of radiation on the ovum is very dependent on age. The older the age, the more sensitive it is to radiation. In addition to sterility, radiation can cause early menopause as a result of hormonal disorders of the reproductive system. The sterility threshold dose according to ICRP 60 is 2.5 - 6 Gy. At a younger age (around 20 years), permanent sterility occurs at higher doses, reaching 12-15 Gy. (Indrati, 2017) (Hiswara, 2015).

In addition to deterministic effects that are limited by threshold doses, radiation has a stochastic effect where the effect size is not determined by the dose size. Stochastic effects that may arise due to radiation exposure are cancer, leukemia, and genetic effects (Indrati, 2017) (Akhadi, 2000) (Yoder, 2010).

$\mathrm{AP}$ and Axial AP projections provide different anatomical information, however, The AP Projections and Axial AP projections give different radiation doses to sensitive organs around the sacrum bone including the right ovary, left ovary, and gonads. Axial AP projection is a projection that can show a clearer image of the sacrum with a minimum radiation dose received by the ovary and gonads.

The image clarity of anatomic information is determined by geometric factors, in this case, the distance between the organ and the radiation source. And the position of the object against the Image Recorder (Bushong, 2016). Axial AP projections produce images that can show the whole sacrum bone with minimal distortion because the central beam is perpendicular to the sacrum bone (Bushong, 2016) (Ballinger, 2016).

Axial AP projection gives a smaller dose in the ovary or gonad than AP projections. The smaller the dose, the effect of radiation on the cause smaller. As far as possible in every examination, the dose received by the patient is as small as possible by the philosophy of radiation safety, namely As Low As Reasonable Achievable (ALARA) (Bapeten, 2014). Even the 
smallest dose of radiation received will have a stochastic effect. (Statkiewcz, 2006) (Bapeten, 2014) (Daryati et al., 2018).

The limitation in this study is that it is carried out on phantoms where the anatomical structure may not be exactly the same as humans. It is recommended that further research be carried out on human objects.

\section{Conclusion}

From this study it can be concluded that there is a difference in anatomical information on the examination of the sacrum between $\mathrm{AP}$ and Axial AP Projection ( $p$-value $=0.017)$, there is a difference in the radiation dose received by the right ovary on the sacrum examination between AP and Axial AP Projection ( $\mathrm{p}$ - value $=0.011$ ), there is a difference in the radiation dose received by the left ovary on the sacral bone examination between $\mathrm{AP}$ and Axial AP projection ( $\mathrm{p}$-value $=0.013$ ), there is a difference in radiation dose received by the gonads on the sacral bone examination between AP and Axial AP projection ( $\mathrm{p}$-value $<0.008$ ). The projection that provides clear anatomical information of the sacral bones and the dose received by the smaller sensitive organs is the AP Axial projection.

\section{Acknowledgments}

Thank you to the Directors of the Politeknik Kesehatan Kemenkes Semarang for the facilities provided so that the research can be carried out. Thank you also for the research submitted to the Chief of BATAN for the collaboration so that this research can be carried out.

\section{References}

Abrahams, R. B, and Huda, W., 2015. X-Ray Based Medical Imaging and Resolution. American Journal of Roentgenology, 204 (4).

Ballinger, Philip W. dan Eugene D. Frank. (2016). Merrill's Atlas of Radiographic Positions and Radiologic Procedures, Tenth Edition, Volume Three. Saint Louis: Mosby.

Bapeten, 2014, Keselamatan Radiasi bidang diagnostik dan Intervensional, BAPETEN, Jakarta

Bontrager, Kenneth 1, 2014. Textbook of Radiographic Positioning and Related Anatomy, Fifth Edition, USA: Mosby

Bushong, Steward C. (2017). Radiologic Science for Technologist, Physics, Biology, and Protection. Eleventh edition, Saint Louis Missouri: Elsevier.
Daryati, S. Katili, M.I. Ardiyanto, J. et all, 2018, The compliance to occupational radiation safety to the baggage fluoroscopy system in international airport, Indian Journal of Public Health Research and Development

Eric K Ofori, William K Antwi, Diane N Scutt, and Matt Ward, 2013, Optimization of patient radiation protection in pelvic $\mathrm{X}$-ray examination in Ghana, Journal of Applied Clinical Medical Physics 13(4):3719

Eric K Ofori, William K Antwi, Diane N Scutt, and Matt Ward, 2013, Patient Radiation Dose Assessment in Pelvic X-ray Examination in Ghana, OMICS Journal of Radiology.

Gonzalez Abel J, Akashi Makoto, Boice Jr John D, Chino, Masamichi, Toshimitsu Homma, Nobuhito Ishigure, Michiaki Kai, Shizuyo Kusumi, Jai-Ki Lee, Hans-Georg Menzel, Ohtsura Niwa, Kazuo Sakai, Wolfgang Weiss, Shunichi Yamashita, and Yoshiharu

Yonekura, 2013, Radiological protection issues arising during and after the Fukushima nuclear reactor accident, IOP Publishing, J. Radiol. Prot. 33 (2013) 497-571

Hiswara E., Dewi Kartikasari. Dosis Pasien Pada Pemeriksaan Rutin Sinar-X Radiologi Diagnostik; 2015 Agustus 15; Jurnal Sains dan Teknologi Nuklir Indonesia. Vol. 16, No 2, Agustus 2015; 71-84

Indrati R, Masrochah S, Susanto E, Kartikasari Y, Wibowo AS, Darmini, Abimanyu B, Rasyid, Murniati E, 2017, Proteksi Radiasi Bidang Radiodiagnostik dan Intervensional, Inti Medika Pustaka Magelang

Indrati R, Wibowo GM, Widyastuti, CIA, Daryati S, Mulyati, S, 2019, Analisis Kecukupan Filter Pada Pesawat Sinar X Super $80 \mathrm{CP}$ dalam hubungannya dengan Entrance Skin Exposure, Prosiding Keselamatan Nuklir, Badan Pengawas Tenaga Nuklir, Universitas Pajajaran Bandung

Indrati, R, Sumala, R, Sudioyono, Daryati S, Analisa Penerimaan Dosis Serap Organ Reproduksi Pada Pemeriksaan Radiografi Abdomen Antara Penggunaan Teknik $k V$ Rendah Dan Teknik kV Tinggi, 2017, Seminar Keselamatan Nuklir, Bapeten, Universitas Gajah Mada.

Akhadi, Mukhlis, "Dasar-Dasar Proteksi Radiasi," Rineka Cipta, Jakarta, 2000.

Taha, MT, FHAl-Ghorabie, RAKutbi, WKSaib, 2015, Assessment of entrance skin doses for patients undergoing diagnostic X-ray examinations in King Abdullah Medical City, Makkah, KSA, Journal of Radiation Research 
Jurnal Riset Kesehatan, 10 (1), 2021, 83 - 83

DOI: 10.31983/jrk.v10i1.6777

and Applied Sciences Volume 8, Issue 1, Pages 100-103

Papp, Jefrey. (2006). Quality Management in The Imaging Science, Third Edition. Saint Louis: Mosby
Stankiewicz, M, A, Paula, J, Russel, E. 2006. Radiation Protection in Medical Radiography. Canada: Mosby Inc

Yoder R. Craig, et all, (2010) Estimating Historical Radiation Doses to a Cohort of US Radiologic Technologists. Radiation Research: 2010, Vol. 166, No. 1, pp. 174-192. 